\title{
Highly Conductive Mn-Co Spinel Powder Prepared by Cu-Doping Used for Interconnect Protection of SOFC
}

\author{
Zhou Jiang ${ }^{1,2}$, Kui Wen ${ }^{2, *}$, Chen Song ${ }^{2}$, Taikai Liu ${ }^{2, *}$, , Yong Dong ${ }^{1}$, Min Liu ${ }^{2}$, Changguang Deng ${ }^{2}$, \\ Chunming Deng ${ }^{2} \mathbb{D}$ and Chenghao Yang ${ }^{3}$ \\ 1 School of Materials and Energy, Guangdong University of Technology, Guangzhou 510640, China; \\ jiangzhou_2019@163.com (Z.J.); yongdong@gdut.edu.cn (Y.D.) \\ 2 National Engineering Laboratory for Modern Materials Surface Engineering Technology, The Key Lab of \\ Guangdong for Modern Surface Engineering Technology, Guangdong Institute of New Materials, \\ Guangdong Academy of Science, Guangzhou 510651, China; songchen@gdinm.com (C.S.); \\ liumin@gdinm.com (M.L.); dengchangguang@gdinm.com (C.D.); dengchunming@gdinm.com (C.D.) \\ 3 School of Environment and Energy, South China University of Technology, Guangzhou 510006, China; \\ esyangc@scut.edu.cn \\ * Correspondence: wenkui@gdinm.com (K.W.); liutaikai@gdinm.com (T.L.)
}

check for updates

Citation: Jiang, Z.; Wen, K.; Song, C.; Liu, T.; Dong, Y.; Liu, M.; Deng, C.; Deng, C.; Yang, C. Highly Conductive Mn-Co Spinel Powder Prepared by $\mathrm{Cu}$-Doping Used for Interconnect Protection of SOFC. Coatings 2021, 11, 1298. https://doi.org/10.3390/ coatings11111298

Academic Editors: Michael Zinigrad and Fabio Palumbo

Received: 8 September 2021

Accepted: 15 October 2021

Published: 26 October 2021

Publisher's Note: MDPI stays neutral with regard to jurisdictional claims in published maps and institutional affiliations.

Copyright: (c) 2021 by the authors. Licensee MDPI, Basel, Switzerland. This article is an open access article distributed under the terms and conditions of the Creative Commons Attribution (CC BY) license (https:/ / creativecommons.org/licenses/by/ $4.0 /)$.

\begin{abstract}
Mn-Co Spinel is considered as one of the most promising materials for the interconnect protection of solid oxide fuel cells; however, its conductivity is too low to maintain a high cell performance as compared with cathode materials. Element doping is an effective method to improve the spinel conductivity. In this work, we proposed doping Mn-Co spinel powder with $\mathrm{Cu}$ via a solid phase reaction. $\mathrm{Cu}_{\delta} \mathrm{Mn}_{1.5-\mathrm{x}} \mathrm{Co}_{1.5-\mathrm{y}} \mathrm{O}_{4}$ with $\delta=0.1,0.2,0.3$, and $\mathrm{x}+\mathrm{y}=\delta$ was obtained. X-ray diffraction (XRD) and thermogravimetry-differential scanning calorimetry (TG-DSC) were used to evaluate the $\mathrm{Cu}$-doping effect. After sintering at $1000{ }^{\circ} \mathrm{C}$ for $12 \mathrm{~h}$, the yield exhibited the best crystallinity, density, and element distribution, with a phase composition of $\mathrm{MnCo}_{2} \mathrm{O}_{4} / \mathrm{Cu}_{\mathrm{x}} \mathrm{Mn}_{3-\mathrm{x}} \mathrm{O}_{4}$ $(\mathrm{x}=1,1.2,1.4$ or 1.5). X-ray photoelectron spectroscopy (XPS) was used to semi-quantitatively characterize the content changes in element valence states. The areal fraction of $\mathrm{Mn}^{2+}$ and $\mathrm{Co}^{3+}$ was found to decrease when the sintering duration increased, which was attributed to the decomposition of the $\mathrm{MnCo}_{2} \mathrm{O}_{4}$ phase. Finally, coatings were prepared by atmospheric plasma spraying with doped spinel powders and the raw powder $\mathrm{Mn}_{1.5} \mathrm{Co}_{1.5} \mathrm{O}_{4}$. It was found that $\mathrm{Cu}$ doping can effectively increase the conductivity of Mn-Co spinel coatings from $23 \mathrm{~S} / \mathrm{cm}$ to $51 \mathrm{~S} / \mathrm{cm}$. Although the dopant $\mathrm{Cu}$ was found to be enriched on the surface of the coatings after the conductivity measurement, which restrained the doping effect, $\mathrm{Cu}$ doping remains a convenient method to significantly promote the conductivity of spinel coatings for SOFC applications.
\end{abstract}

Keywords: Mn-Co spinel; Cu doping; conductivity; SOFC; interconnect

\section{Introduction}

Solid oxide fuel cells (SOFC) are high-temperature energy conversion devices that can directly convert the chemical energy of fuel into electrical energy. They mainly consist of a porous anode/cathode, a dense electrolyte, and an interconnect. As an important part, the interconnect provides electrical contact between cells while isolating fuel gas from air. Ferritic stainless steel (FSS) has been widely used as interconnect material due to its outstanding oxidation resistance and suitable thermal expansion coefficient [1-3]. However, at elevated temperature, the $\mathrm{Cr}$ of FSS is oxidized to form $\mathrm{Cr}_{2} \mathrm{O}_{3}, \mathrm{CrO}_{3}$, or even $\mathrm{CrO}_{2}(\mathrm{OH})_{2}$. These substances can accumulate at the cathode and react with cathode materials, forming a low active phase and deteriorating cell performance. At present, the above problems are mainly solved by introducing protective coatings $[4,5]$.

$(\mathrm{Mn}, \mathrm{Co})_{3} \mathrm{O}_{4}$ spinel coating is often used to diminish the evaporation of $\mathrm{Cr}$ and thus reduce the performance degradation and prolong the service life of the stack. However, 
the theoretical conductivity of $(\mathrm{Mn}, \mathrm{Co})_{3} \mathrm{O}_{4}$ spinel at elevated temperature is only $60 \mathrm{~S} / \mathrm{cm}$, which is much lower than that of the cathode material, such as LSCF $>200 \mathrm{~S} / \mathrm{cm}$ at 600-800 ${ }^{\circ} \mathrm{C}$ [6-9]. Many efforts have been made to improve the conductivity of Mn-Co spinel coating. Fe doping can reduce the growth of $\mathrm{Cr}_{2} \mathrm{O}_{3}$ film and improve the oxidation resistance, but this reduces the conductivity of spinel coatings [10-13]. Ce doping can enhance the adhesion and improve the interfacial stability of oxide film, but the effects depend on the substrate materials [14-16]. Cu doping can improve the conductivity and adjust the thermal expansion coefficient of spinel coatings [17-19].

For promoting the conductivity of Mn-Co spinel coatings, in this work, we prepared $\mathrm{Cu}$-doped Mn-Co spinel powder via the solid-phase reaction method. The doped powder was denoted as $\mathrm{Cu}_{\delta} \mathrm{Mn}_{1.5-\mathrm{x}} \mathrm{Co}_{1.5-\mathrm{y}} \mathrm{O}_{4}(\delta=0.1,0.2,0.3, \mathrm{x}+\mathrm{y}=\delta)$. The first part of this work was to study the optimal doping amount of $\mathrm{Cu}$, and then the doping conditions were studied to improve the doping effect. Finally, the doped powder was used to prepare coatings on FSS substrate to evaluate the doping effect using a plasma spray.

\section{Experiment}

\subsection{Powder Preparation and Characterization}

The raw materials, as shown in Figure 1, were $\mathrm{Cu}$ powders (Tijo, Changsha, China) with $\mathrm{D}_{50}=21.58 \mu \mathrm{m}$, and $\mathrm{Mn}_{1.5} \mathrm{Co}_{1.5} \mathrm{O}_{4}$ powder with $\mathrm{D}_{50}=19.2 \mu \mathrm{m}$ (Terio, Qingdao, China). Three groups of doping powder were prepared with controlled $\mathrm{Cu}$-doping as shown in Table 1 . The raw powders were mechanically mixed in a roller mixer at a speed of $600 \mathrm{r} / \mathrm{min}$ for $20 \mathrm{~h}$. After mixing, the powders were transferred into a muff furnace for solid-phase reaction sintering, and then the sintered powders were sieved to maintain the particle size below $50 \mu \mathrm{m}$. The phase structure of the sieved powders was checked by X-ray diffraction (XRD, Bruker D8 Advance, Bruker Cop., Karlsruhe, Germany) in the range of 10-90 $\left(0.01^{\circ} /\right.$ step, $0.167 \mathrm{~s} /$ step $)$. The micromorphology and element distribution of the sieved powders were characterized by a scanning electron microscope (SEM, Nova-Nano-450, FEI, Hillsboro, OR, USA) and energy dispersive spectrometer (EDS, XLT TEM-SDD, AMETEK EDAX, Philadelphia, PA, USA). The solid-phase sintering process was investigated using a thermogravimetry-differential scanning calorimetry (TG-DSC, STA-449-F5, NETZSCH, Selb, Germany) test with a heating rate of $5{ }^{\circ} \mathrm{C} / \mathrm{min}$ in air. The valence states of the sintered powders were analyzed by X-ray photoelectron spectroscopy (XPS, Thermo Fisher Scientific Nexsa, Thermo Fisher Scientific Inc., Waltham, MA, USA), and then the content changes in the element valence states were characterized semi-quantitatively. The XPS spectra were obtained with monochromatized $\mathrm{Al} \mathrm{K} \alpha$ radiation. All spectra were recorded at a take-off angle of $90^{\circ}$. The carbon C 1s peak with a binding energy of $284.5 \mathrm{eV}$ was used for calibration.
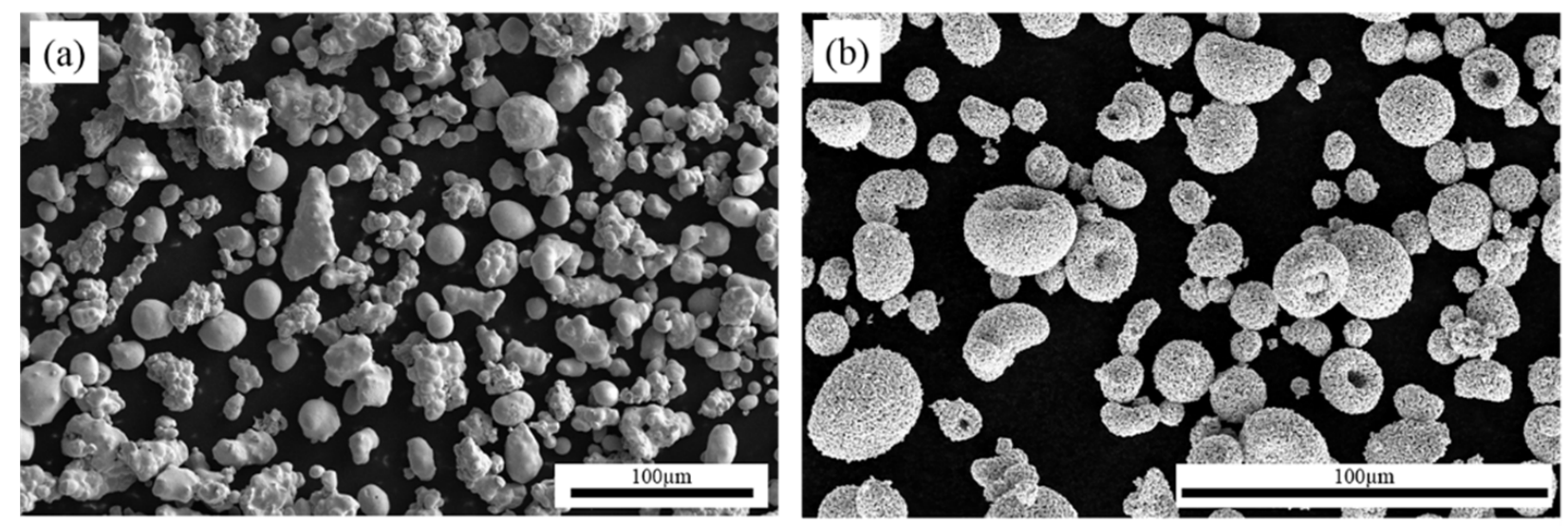

Figure 1. The morphology of $\mathrm{Cu}$ powder (a) and $\mathrm{Mn}_{1.5} \mathrm{Co}_{1.5} \mathrm{O}_{4}$ powder (b). 
Table 1. The raw material ratio to prepare $\mathrm{Cu}_{\delta} \mathrm{Mn}_{1.5-\mathrm{x}} \mathrm{Co}_{1.5-\mathrm{y}} \mathrm{O}_{4}$ powders.

\begin{tabular}{cccc}
\hline Mass Percentage (wt\%) & $\boldsymbol{\delta}=\mathbf{0 . 1}$ & $\boldsymbol{\delta}=\mathbf{0 . 2}$ & $\boldsymbol{\delta}=\mathbf{0 . 3}$ \\
\hline $\mathrm{Cu}$ Powder & 2.7 & 5.4 & 8.0 \\
$\mathrm{Mn}_{1.5} \mathrm{Co}_{1.5} \mathrm{O}_{4}$ Power & 97.3 & 94.6 & 92.0 \\
\hline
\end{tabular}

\subsection{Coating Preparation}

$\mathrm{Al}_{2} \mathrm{O}_{3}$ sheets $(\varphi 18.55 \mathrm{~mm} \times 1.65 \mathrm{~mm})$ were used as substrates. $\mathrm{Mn}_{1.5} \mathrm{Co}_{1.5} \mathrm{O}_{4}$ and doped $\mathrm{Cu}_{0.3} \mathrm{Mn}_{1.5-\mathrm{x}} \mathrm{Co}_{1.5-\mathrm{y}} \mathrm{O}_{4}$ powders were used as spraying feedstocks. Atmospheric plasma spraying equipment (model CLWI-091, GTV, Luckenbach, Germany) was used to prepare the spinel coating. The spraying process parameters are shown in Table 2. Before spraying, substrates were ultrasonically cleaned with alcohol to remove any oil and impurities on the surface.

Table 2. Spray parameters to prepare Cu-doped Mn-Co spinel coatings.

\begin{tabular}{cccccc}
\hline \multicolumn{2}{c}{ Gas Flow (NL/min) } & Current (A) & Gun Speed (mm/s) & Powder Feeding Rate (g/min) & Spray Distance (mm) \\
\hline $\mathrm{Ar} / 72$ & $\mathrm{H}_{2} / 8$ & 620 & 800 & 15 & 110 \\
\hline
\end{tabular}

\subsection{Coating Characterization}

The sectional morphology, density, and element distribution of the spinel coating were analyzed by SEM and EDS. The phase composition of the coating was characterized by XRD. The conductivity of coatings was determined by the four-probe method. The conductivity test setup is shown in Figure 2. Testing samples were placed in a tubular furnace, which was heated up to $800{ }^{\circ} \mathrm{C}$ at a rate of $5{ }^{\circ} \mathrm{C} / \mathrm{min}$. A constant current of $0.2 \mathrm{~A}$ was provided between $\mathrm{I}^{+}$and $\mathrm{I}^{-}$through silver lines, and the corresponding voltage between $\mathrm{U}^{+}$and $\mathrm{U}^{-}$was recorded. The coating conductivity $(\varepsilon, \mathrm{S} / \mathrm{cm})$ was obtained as $\varepsilon=1 \div(\mathrm{C} \times \mathrm{R} \times \mathrm{W})$, where $\mathrm{C}$ denotes the wiring coefficient, $\mathrm{R}$ denotes the calculated resistance $(\Omega)$, and $W$ denotes the thickness of the coating $(\mathrm{cm})$.

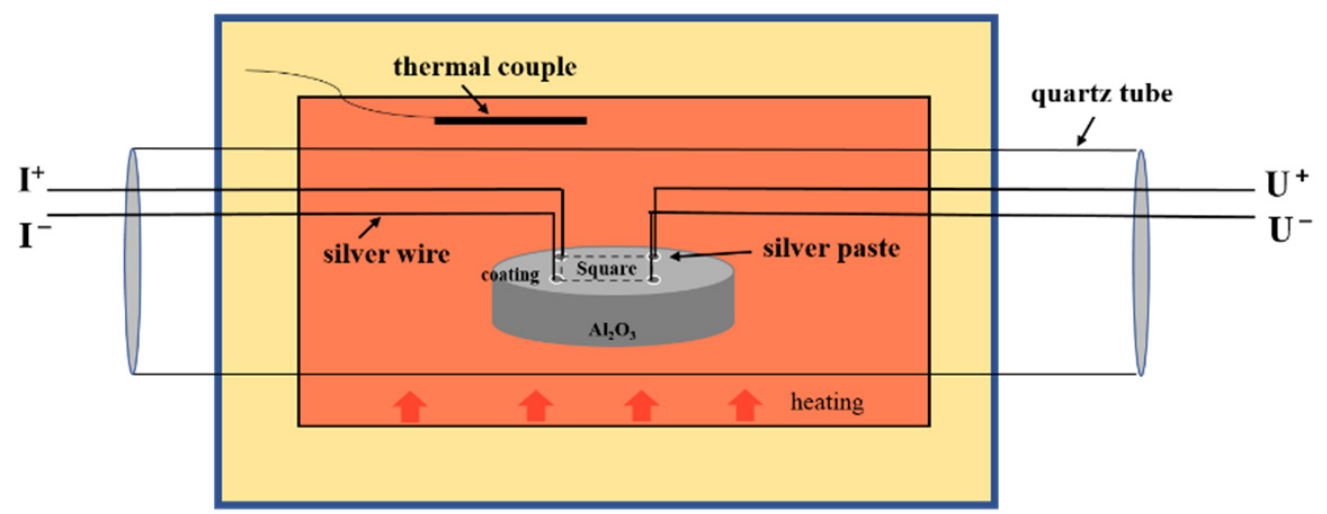

Figure 2. Illustration of the conductivity measurements setup.

\section{Results and Discussion}

\subsection{Phases and Structures}

Figure 3 shows the XRD patterns of $\mathrm{Cu}_{\delta} \mathrm{Mn}_{1.5-\mathrm{x}} \mathrm{Co}_{1.5-\mathrm{y}} \mathrm{O}_{4}(\delta=0,0.1,0.2,0.3, \mathrm{x}+\mathrm{y}=\delta)$ powders sintered at $900{ }^{\circ} \mathrm{C}$ for $12 \mathrm{~h} . \mathrm{Cu}_{\delta} \mathrm{Mn}_{1.5-\mathrm{x}} \mathrm{Co}_{1.5-\mathrm{y}} \mathrm{O}_{4}(\delta=0.1,0.2,0.3)$ powders were composed of $\mathrm{CuO}, \mathrm{MnCo}_{2} \mathrm{O}_{4}, \mathrm{Cu}_{\mathrm{x}} \mathrm{Mn}_{3-\mathrm{x}} \mathrm{O}_{4}\left(\mathrm{x}=1,1.2,1.4\right.$, or 1.5), and $(\mathrm{Co}, \mathrm{Mn})(\mathrm{Co}, \mathrm{Mn})_{2} \mathrm{O}_{4}$. $(\mathrm{Co}, \mathrm{Mn})(\mathrm{Co}, \mathrm{Mn})_{2} \mathrm{O}_{4}$ is a mixture of $\mathrm{MnCo}_{2} \mathrm{O}_{4}$ and $\mathrm{CoMn}_{2} \mathrm{O}_{4}$. Cu-doping can promote the formation of the cubic spinel phase. After increasing the amount of $\mathrm{Cu}$-doping, the diffraction peaks were found to shift slightly toward the right because of the replacement of $\mathrm{Co}^{2+}(0.074 \mathrm{~nm})$ with $\mathrm{Cu}^{2+}(0.073 \mathrm{~nm})$, and the diffraction intensity of $(\mathrm{Co}, \mathrm{Mn})(\mathrm{Co}, \mathrm{Mn}){ }_{2} \mathrm{O}_{4}$ and $\mathrm{CuO}$ was found to decrease, which indicates the doping reactions had taken place. 
When both $\mathrm{CuO}$ and $\mathrm{CoMn}_{2} \mathrm{O}_{4}$ were present in the coating, the uniformity and conductivity of the powder were reduced [18]. It was found that the $(\mathrm{Co}, \mathrm{Mn})(\mathrm{Co}, \mathrm{Mn})_{2} \mathrm{O}_{4}$ and $\mathrm{CuO}$ of $\mathrm{Cu}_{0.3} \mathrm{Mn}_{1.5-\mathrm{x}} \mathrm{Co}_{1.5-\mathrm{y}} \mathrm{O}_{4}$ powder exhibited the lowest diffraction intensity and the best crystallinity of the spinel phase.

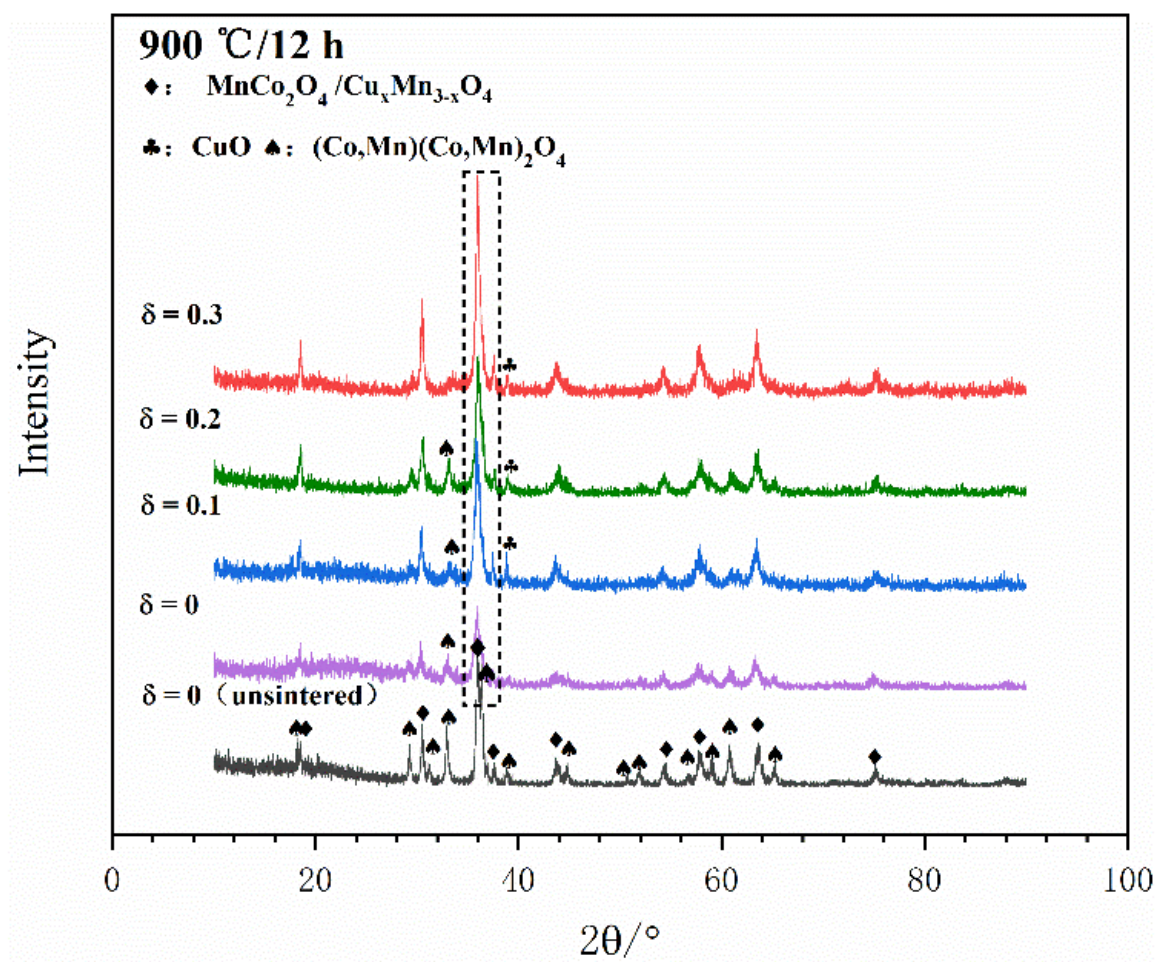

Figure 3. XRD patterns of $\mathrm{Mn}_{1.5} \mathrm{Co}_{1.5} \mathrm{O}_{4}$ powder and $\mathrm{Cu}_{\delta} \mathrm{Mn}_{1.5-0.5 \mathrm{x}} \mathrm{Co}_{1.5-0.5 \mathrm{x}} \mathrm{O}_{4}$ powder.

\subsection{Solid Phase Reactions}

$\mathrm{Cu}_{\delta} \mathrm{Mn}_{1.5-\mathrm{x}} \mathrm{Co}_{1.5-\mathrm{y}} \mathrm{O}_{4}(\delta=0,0.1,0.2,0.3)$ powders were tested by TG-DSC to evaluate the physical and chemical changes during sintering. According to the TG curve in Figure 4a and the subsequent XRD analysis (Figure 5), it was found that the powders gained some weight at $500-800{ }^{\circ} \mathrm{C}$, which was mainly attributed to the oxidization of $\mathrm{Cu}$ to $\mathrm{CuO}$. However, at $800-1000^{\circ} \mathrm{C}$, the powder weights were found to decrease slightly and the $\mathrm{CuO}$ had disappeared. At $1034{ }^{\circ} \mathrm{C}$, the powder weight was slightly decreased again, which might be related to the decomposition of the spinel phase. Then, the powder was found to lose weight violently between $1200-1300{ }^{\circ} \mathrm{C}$, which indicates that the spinel phases were decomposed. As shown in Figure $4 \mathrm{~b}$, the commercial $\mathrm{Mn}_{1.5} \mathrm{Co}_{1.5} \mathrm{O}_{4}$ powder had no endothermic peak at $1034{ }^{\circ} \mathrm{C}$, while $\mathrm{Cu}_{\delta} \mathrm{Mn}_{1.5-\mathrm{x}} \mathrm{Co}_{1.5-\mathrm{y}} \mathrm{O}_{4}(\delta=0.1,0.2,0.3)$ powder had an endothermic peak. According to public reports [9,13,20,21], the formation of $\mathrm{Cu}_{\mathrm{x}} \mathrm{Mn}_{3-\mathrm{x}} \mathrm{O}_{4}$ and $\mathrm{MnCo}_{2} \mathrm{O}_{4}$ is an exothermic process. Since the $\mathrm{MnCo}_{2} \mathrm{O}_{4}$ phase of the commercial $\mathrm{Mn}_{1.5} \mathrm{Co}_{1.5} \mathrm{O}_{4}$ powder showed no significant decomposition at $1034{ }^{\circ} \mathrm{C}$, it was inferred that the endothermic peak at $1034{ }^{\circ} \mathrm{C}$ was the result of the decomposition of $\mathrm{Cu}_{\mathrm{x}} \mathrm{Mn}_{3-\mathrm{x}} \mathrm{O}_{4}$. Furthermore, in the range $1100-1300{ }^{\circ} \mathrm{C}$, after increasing the amount of $\mathrm{Cu}$, the TG curve shifted toward the left, and the stable temperature of the spinel phases decreased. The DSC curves were found to gradually flatten and continuously exhausted heat. As shown in Figure $4 \mathrm{c}, \mathrm{d}$, the $\mathrm{Cu}_{0.3} \mathrm{Mn}_{1.5-\mathrm{x}} \mathrm{Co}_{1.5-\mathrm{y}} \mathrm{O}_{4}$ powder exhibited the best crystallization. In conclusion, $\mathrm{Cu}_{x} \mathrm{Mn}_{3-\mathrm{x}} \mathrm{O}_{4}$ spinel was successfully synthesized between $900{ }^{\circ} \mathrm{C}$ and $1034{ }^{\circ} \mathrm{C}$. The powders with $\delta=0.3$ had the best crystallinity of spinel phases and consisted of more conductive spinel phase. 

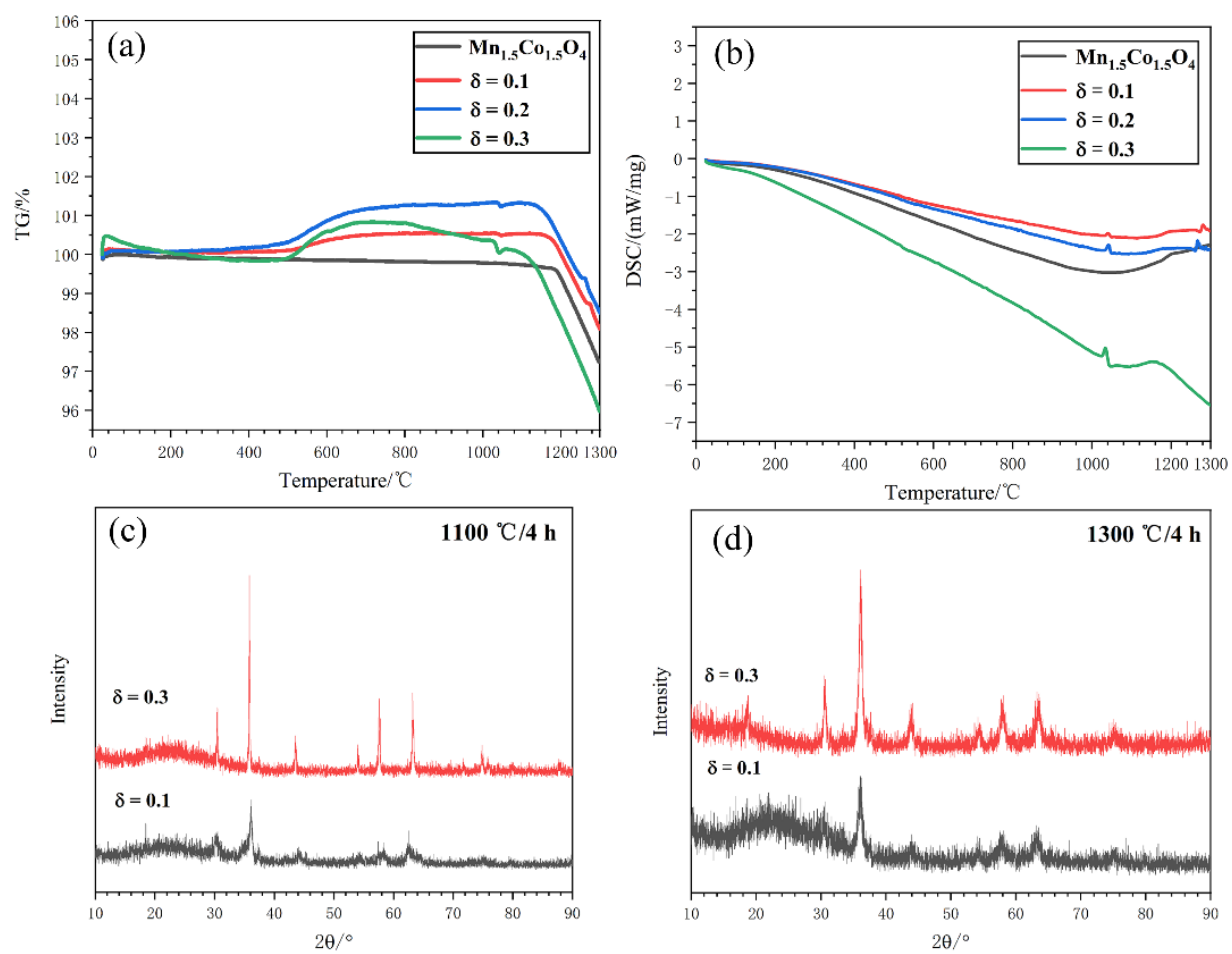

Figure 4. (a) TG curves of $\mathrm{Cu}_{\delta} \mathrm{Mn}_{1.5-\mathrm{x}} \mathrm{Co}_{1.5-\mathrm{y}} \mathrm{O}_{4}$ powders; (b) DSC curve; (c) XRD patterns of powder sintered at $1100{ }^{\circ} \mathrm{C}$ for $4 \mathrm{~h}$ with $\delta=0.1$ and 0.3 ; (d) XRD patterns of powder sintered at $1300{ }^{\circ} \mathrm{C}$ for $4 \mathrm{~h}$ with $\delta=0.1$ and 0.3 .
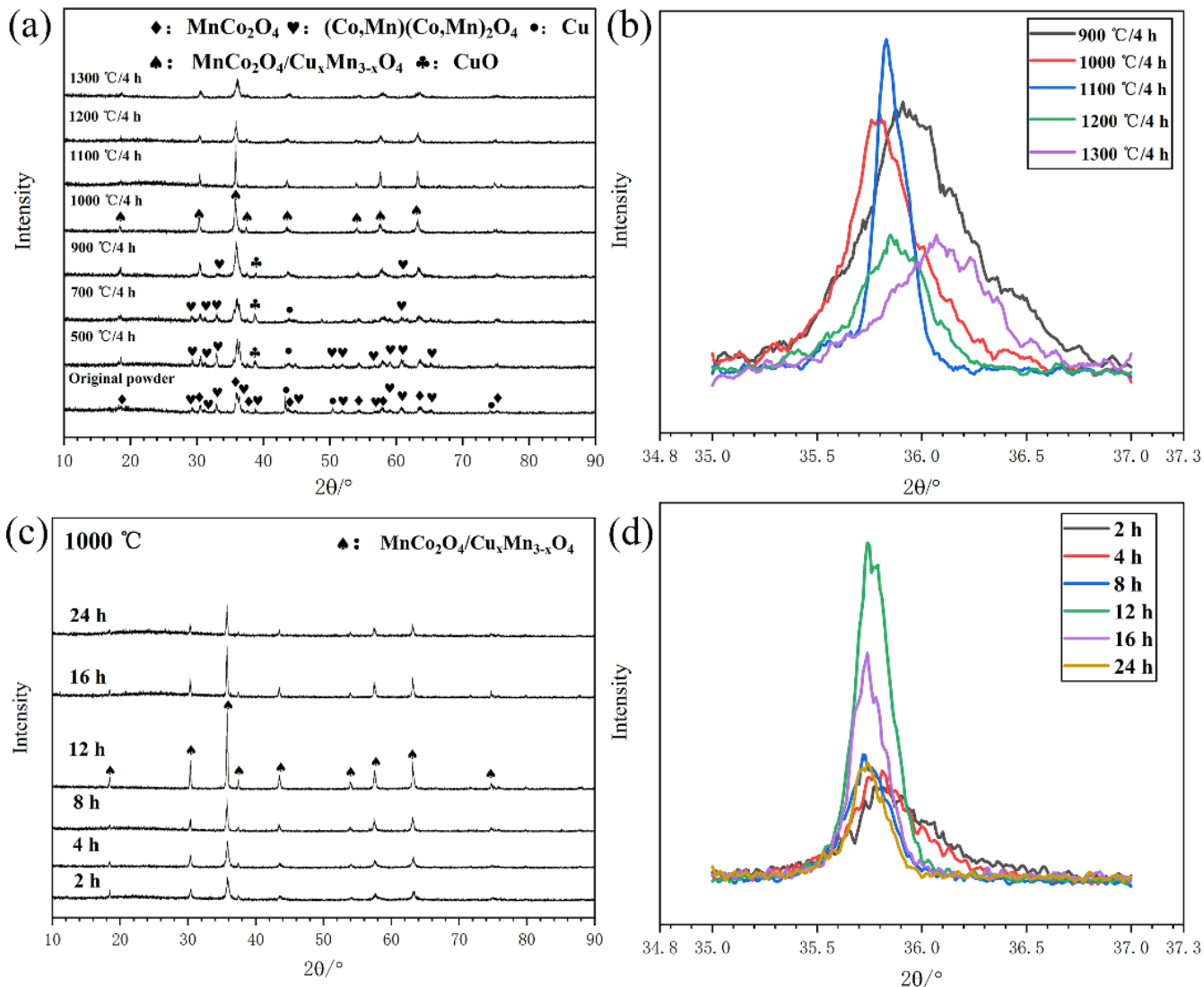

Figure 5. XRD patterns of doped powders sintered under different conditions: $(\mathbf{a}, \mathbf{b}) 500-1300{ }^{\circ} \mathrm{C}$ for $4 \mathrm{~h} ;(\mathbf{c}, \mathrm{d}) 1000^{\circ} \mathrm{C}$ for $2-24 \mathrm{~h}$. 


\subsection{Sintering Conditions}

$\mathrm{Cu}_{0.3} \mathrm{Mn}_{1.5-\mathrm{x}} \mathrm{Co}_{1.5-\mathrm{y}} \mathrm{O}_{4}$ powders were prepared at controlled sintering temperatures and durations. $\mathrm{Cu}$ was introduced into the spinel lattice by sintering. The more $\mathrm{Cu}$ that entered the spinel lattice, the better the conductivity of the coating. The phase composition, crystallization, and surface morphology of the prepared $\mathrm{Cu}_{0.3} \mathrm{Mn}_{1.5-\mathrm{x}} \mathrm{Co}_{1.5-\mathrm{y}} \mathrm{O}_{4}$ powders were specifically investigated. According to the XRD patterns of the powders sintered at $500-1300{ }^{\circ} \mathrm{C}$ for $4 \mathrm{~h}$, it was found that, with the increase in sintering temperature, the abundance of $\mathrm{CuO}$ and $(\mathrm{Co}, \mathrm{Mn})(\mathrm{Co}, \mathrm{Mn})_{2} \mathrm{O}_{4}$ phases reduced, while the abundance of $\mathrm{MnCo}_{2} \mathrm{O}_{4} / \mathrm{Cu}_{\mathrm{x}} \mathrm{Mn}_{3-\mathrm{x}} \mathrm{O}_{4}$ spinel phases increased. The crystallinity of the spinel phases increased firstly and then decreased as the temperature increased; thus, the best crystallization temperature was between $1000-1100{ }^{\circ} \mathrm{C}$, as shown in Figure 5. According to the morphology of the sintered powders, the powder density was found to increase when the temperature increased from $900{ }^{\circ} \mathrm{C}$ to $1300^{\circ} \mathrm{C}$. After sintering between $1100-1300{ }^{\circ} \mathrm{C}$, the powder was found to be severely agglomerated, as shown in Figure 6, while at $1000^{\circ} \mathrm{C}$, the powder porosity was reduced.
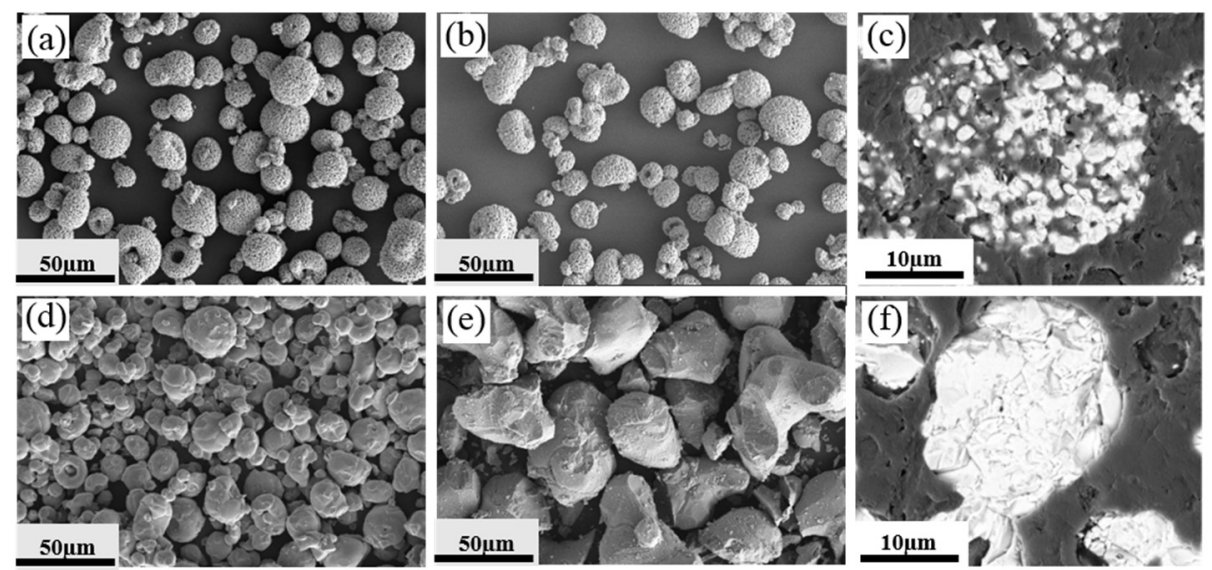

Figure 6. The morphology of $\mathrm{Cu}_{0.3} \mathrm{Mn}_{1.5-\mathrm{x}} \mathrm{Co}_{1.5-\mathrm{y}} \mathrm{O}_{4}$ powders sintered at: (a) $900{ }^{\circ} \mathrm{C}$ for $12 \mathrm{~h}$; (b) $1000{ }^{\circ} \mathrm{C}$ for $12 \mathrm{~h}$; (c) $1000{ }^{\circ} \mathrm{C}$ for $12 \mathrm{~h}$ (cross-sectional); (d) $1100{ }^{\circ} \mathrm{C}$ for $4 \mathrm{~h}$; (e) $1300{ }^{\circ} \mathrm{C}$ for $4 \mathrm{~h}$; (f) $1100^{\circ} \mathrm{C}$ for $4 \mathrm{~h}$ (cross-sectional).

After sintering at $1000{ }^{\circ} \mathrm{C}$ for $2 \mathrm{~h}, 4 \mathrm{~h}, 8 \mathrm{~h}, 12 \mathrm{~h}, 16 \mathrm{~h}$, and $24 \mathrm{~h}$, the intensity of the diffraction peak and crystallinity of spinel were found to firstly increase and then decrease after $12 \mathrm{~h}$. The change in diffraction peaks was related to the amount of spinel phases. The diffraction intensity of powder sintered for $12 \mathrm{~h}$ was the highest and the crystallinity was the best, as shown in Figure 5c,d. In Figure 7, EDS analysis showed a uniform distribution of $\mathrm{Cu}$, which indicates that the $\mathrm{Cu}$ has been sucessfully doped into $\mathrm{Mn}_{1.5} \mathrm{Co}_{1.5} \mathrm{O}_{4}$ spinel powders. In conclusion, $1000{ }^{\circ} \mathrm{C} / 12 \mathrm{~h}$ was the best condition for $\mathrm{Cu}$ doping.
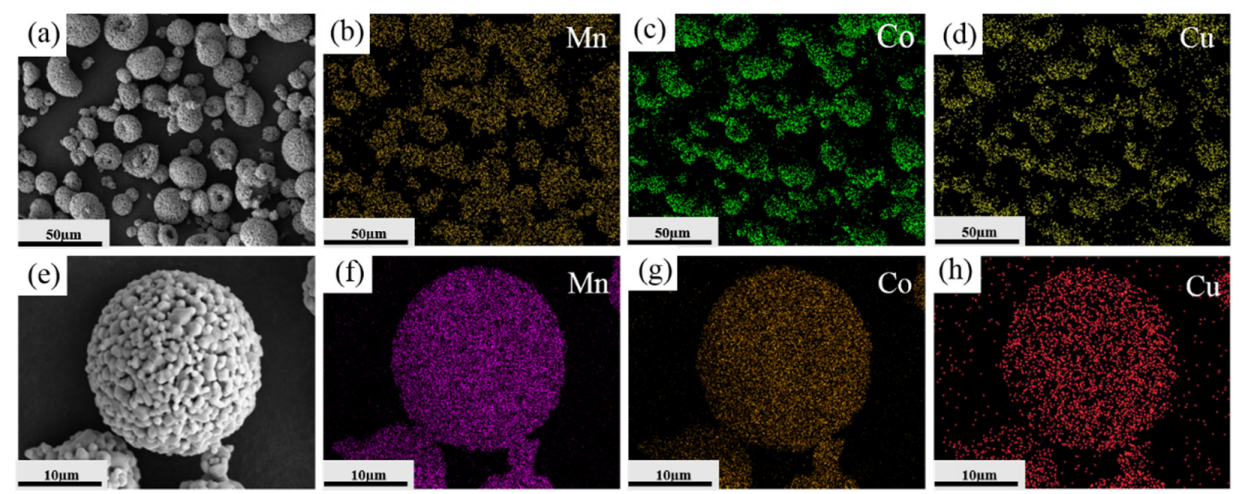

Figure 7. The morphology and elements distribution of $\mathrm{Cu}_{0.3} \mathrm{Mn}_{1.5-\mathrm{x}} \mathrm{Co}_{1.5-\mathrm{y}} \mathrm{O}_{4}$ powders sintered at $1000{ }^{\circ} \mathrm{C}$ for $12 \mathrm{~h} \mathrm{(a-d)} \mathrm{low} \mathrm{magnification;} \mathrm{(e-h)} \mathrm{high} \mathrm{magnification.}$ 


\subsection{Stability of Doped Powders}

As Cu-Mn spinel is less stable than Mn-Co spinel at elevated temperature, when doping $\mathrm{Mn}-\mathrm{Co}$ spinel with $\mathrm{Cu}$ to improve the conductivity, the stability of the obtained spinel is reduced. After being sintered at $1000{ }^{\circ} \mathrm{C}$ for $4 \mathrm{~h}, 12 \mathrm{~h}$, and $24 \mathrm{~h}$ to allow the doping, the $\mathrm{Cu}_{0.3} \mathrm{Mn}_{1.5-\mathrm{x}} \mathrm{Co}_{1.5-\mathrm{y}} \mathrm{O}_{4}$ powder was heated to $800{ }^{\circ} \mathrm{C}$ and maintained in that state for $12 \mathrm{~h}$ to evaluate the stability. In Figure $8 \mathrm{a}$, the XRD patterns before and after the heat treatment are presented. The $\mathrm{MnCo}_{2} \mathrm{O}_{4} / \mathrm{Cu}_{x} \mathrm{Mn}_{3-\mathrm{x}} \mathrm{O}_{4}$ phase was detected after the heat treatment, but the diffraction intensity was significantly diminished. TG and DSC tests were performed from room temperature to $800^{\circ} \mathrm{C}$ with a ramping rate of $5{ }^{\circ} \mathrm{C} / \mathrm{min}$, and a preservation stage of $12 \mathrm{~h}$, in order to study the stability of the doped powders. It was found that during ramping, the DSC plots showed evident exothermic behavior. However, during the following preservation stage, both the TG and DSC curves exhibited a linear behavior in which no endothermic and exothermic peak was visible, as shown in Figure $8 \mathbf{b}-\mathrm{d}$. This indicates that the doped powder had a good stability during the preservation process. For the $\mathrm{Cu}_{\mathrm{x}} \mathrm{Mn}_{3-\mathrm{x}} \mathrm{O}_{4}$ powder, when $\mathrm{x}=1.2,1.4,1.5$, the $\mathrm{CuO}$ and spinel phase coexisted at $800^{\circ} \mathrm{C}$. However, according to the XRD and DSC patterns, it can be seen that the decomposition of $\mathrm{Cu}_{\mathrm{x}} \mathrm{Mn}_{3-\mathrm{x}} \mathrm{O}_{4}$ spinel did not occur and $\mathrm{CuO}$ was not formed. Therefore, the $\mathrm{Cu}_{\mathrm{x}} \mathrm{Mn}_{3-\mathrm{x}} \mathrm{O}_{4}$ phase was mainly composed of the $\mathrm{CuMn}_{2} \mathrm{O}_{4}$ phase. In conclusion, the $\mathrm{MnCo}_{2} \mathrm{O}_{4} / \mathrm{CuMn}_{2} \mathrm{O}_{4}$ phase in the powder can exist stably at $800{ }^{\circ} \mathrm{C}$.
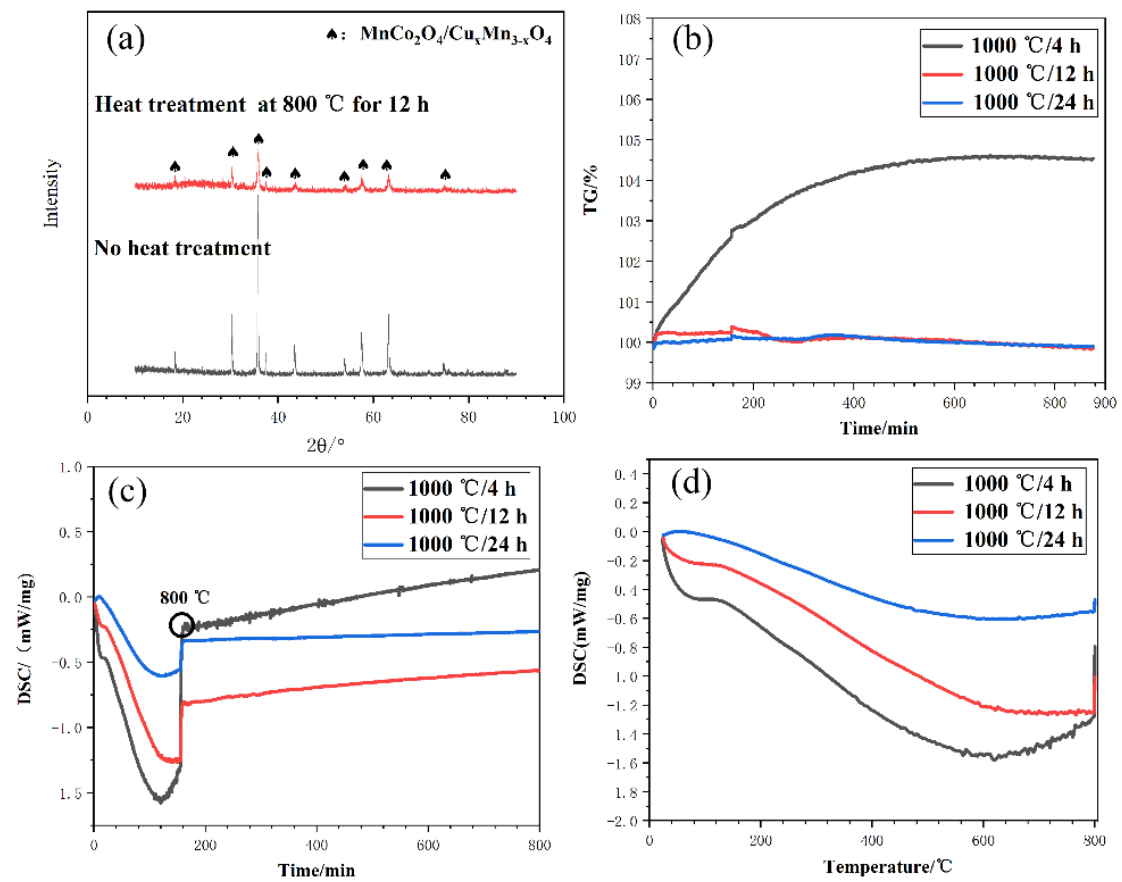

Figure 8. (a) XRD patterns before and after heating at $800^{\circ} \mathrm{C}$ of powder sintered at $1000{ }^{\circ} \mathrm{C}$ for $12 \mathrm{~h}$; $(\mathbf{b}, \mathbf{c})$ TG-DSC curves of powders sintered at $1000^{\circ} \mathrm{C}$ for $4 \mathrm{~h}, 12 \mathrm{~h}$, and $24 \mathrm{~h}$; (d) DSC curves during the heating process.

\subsection{Elemental Composition}

To determine the elemental composition and valence states of $\mathrm{Cu}_{0.3} \mathrm{Mn}_{1.5-\mathrm{x}} \mathrm{Co}_{1.5-\mathrm{y}} \mathrm{O}_{4}$ powders, XPS tests were carried out. As shown in Figure $9 \mathrm{a}, \mathrm{Co}, \mathrm{Mn}, \mathrm{Cu}, \mathrm{O}$, and $\mathrm{C}$ were identified in the coating. According to the Co $2 p$ spectrum in Figure $9 b$, the low-energy peaks $(780.6$ and $796.1 \mathrm{eV}$ ) and high-energy peaks (781.6 and $797.4 \mathrm{eV})$ in the Co $2 \mathrm{P}_{3 / 2}$ and $2 \mathrm{P}_{1 / 2}$ regions were ascribed to $\mathrm{Co}^{3+}$ and $\mathrm{Co}^{2+}$, respectively. In addition, the peaks with binding energies of $786.6 \mathrm{eV}$ and $803.6 \mathrm{eV}$ were identified as the satellite peaks of $\mathrm{Co}^{2+}$ and $\mathrm{Co}^{3+}$ [22-24]. As illustrated in Figure 9c, the peaks at $641.5,642.3$, and $642.8 \mathrm{eV}$ corresponded to $\mathrm{Mn}^{2+}, \mathrm{Mn}^{3+}$, and $\mathrm{Mn}^{4+}$, respectively [25-27]. In Figure 9d, the peaks at $945 \mathrm{eV}$ were attributed to $\mathrm{Cu}^{2+}$ satellites, while those at 930.8 and $933.4 \mathrm{eV}$ were evidence 
of the presence of $\mathrm{Cu}^{+}$and $\mathrm{Cu}^{2+}$ in the $\mathrm{Cu} 2 \mathrm{P}_{3 / 2}$ orbital peaks. Peaks at 953.5 and $950.6 \mathrm{eV}$ can be assigned to the existence of $\mathrm{Cu}^{2+}$ and $\mathrm{Cu}^{+}$, which were observed in the $\mathrm{Cu} 2 \mathrm{P}_{1 / 2}$ orbital [28-30]. The peaks at $530.4 \mathrm{eV}$ and $531.9 \mathrm{eV}$, as shown in Figure 9e, corresponded to the oxygen-metal bond (metal $=\mathrm{Mn}, \mathrm{Co}$ ) and $\mathrm{O}-\mathrm{H}$ bond in the spinel phase, respectively [3]
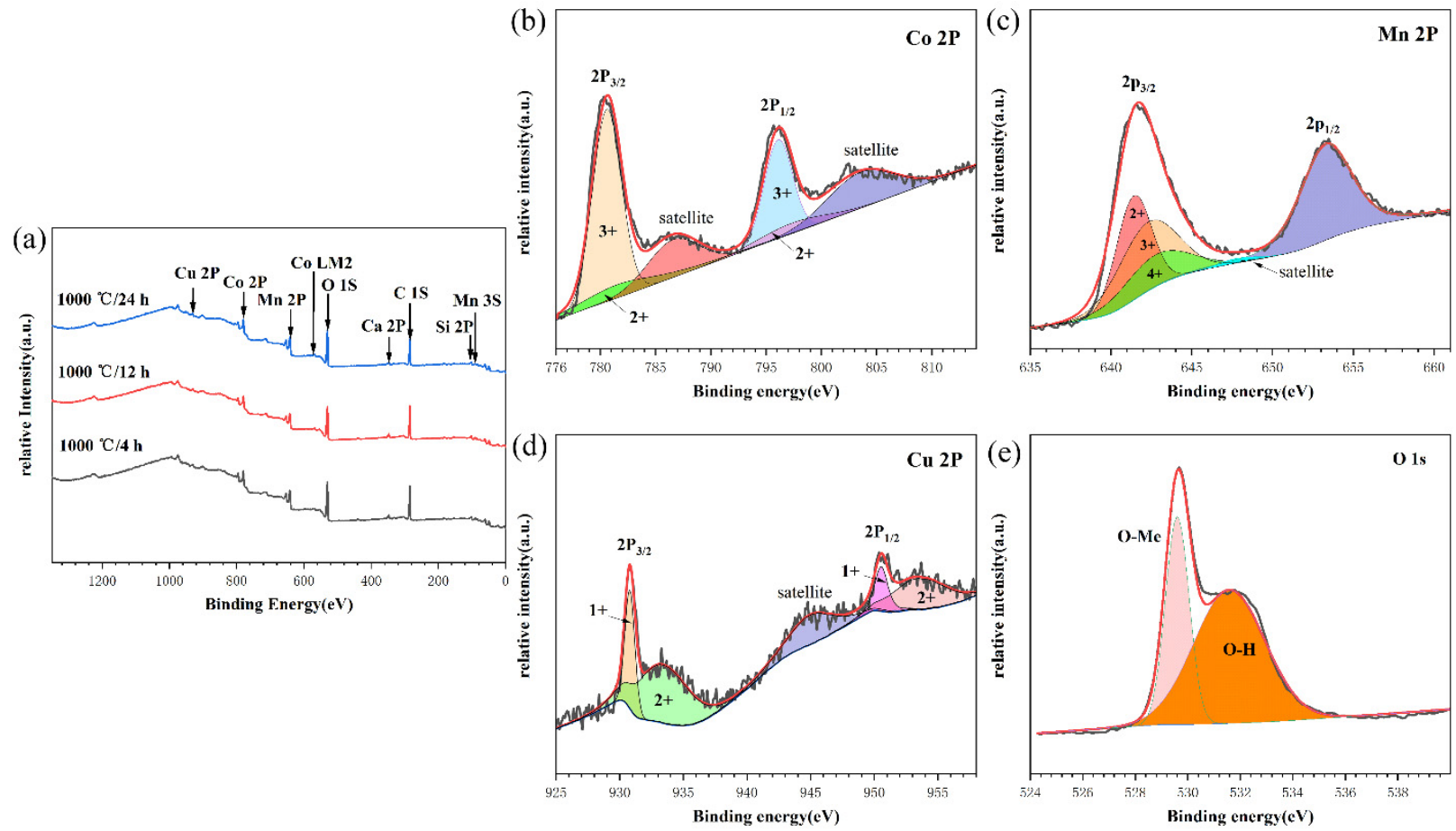

Figure 9. XPS spectra of $\mathrm{Cu}_{0.3} \mathrm{Mn}_{1.5-\mathrm{x}} \mathrm{Co}_{1.5-\mathrm{y}} \mathrm{O}_{4}$ powders sintered at $1000{ }^{\circ} \mathrm{C}$ : (a) survey; (b) Co $2 \mathrm{P}$ of $1000{ }^{\circ} \mathrm{C} / 12 \mathrm{~h}$ sample; (c) $\mathrm{Mn} 2 \mathrm{P}$ of $1000^{\circ} \mathrm{C} / 12 \mathrm{~h}$ sample; (d) Cu $2 \mathrm{P}$ of $1000^{\circ} \mathrm{C} / 12 \mathrm{~h}$ sample; (e) $\mathrm{O} 1$ s of $1000^{\circ} \mathrm{C} / 12 \mathrm{~h}$ sample.

According to public reports [10,31,32], various valences exist in $\mathrm{Mn}-\mathrm{Co}-\mathrm{Cu}$ spinel. By performing a deconvolution of the XPS spectra, the relative proportion of different valence states of elements can be obtained. The relative proportion is listed in Table 3. It was found that the relative proportion of $\mathrm{Mn}^{3+}$ increased to $41.3 \%$ when sintered for $12 \mathrm{~h}$ and then decreased $33.6 \%$ after $24 \mathrm{~h}$ of preservation. The areal fraction of $\mathrm{Mn}^{2+}$ and $\mathrm{Co}^{3+}$ increased first and then decreased when the sintering duration increased. The increase in $\mathrm{Mn}^{3+}$ indicated an increase in the $\mathrm{CuMn}_{2} \mathrm{O}_{4}$ phase, and the decrease in $\mathrm{Mn}^{2+}$ and $\mathrm{Co}^{3+}$ was related to the decomposition of the $\mathrm{MnCo}_{2} \mathrm{O}_{4}$ phase. Moreover, the increase in $\mathrm{Mn}^{4+}$ indicated an increase in $\mathrm{MnO}_{2}$, which diminished the conductivity of the prepared powders or coatings. According to Table 3 the powder prepared at $1000{ }^{\circ} \mathrm{C}$ and sintered for $12 \mathrm{~h}$ gave the most $\mathrm{MnCo}_{2} \mathrm{O}_{4}$ and $\mathrm{CuMn}_{2} \mathrm{O}_{4}$.

Table 3. Areal fractions of Mn and Co in the powders prepared under different conditions.

\begin{tabular}{ccccc}
\hline \multirow{2}{*}{ Element State } & \multicolumn{4}{c}{ Areal Fraction (\%) } \\
\cline { 2 - 5 } & $\mathbf{1 0 0 0}{ }^{\circ} \mathbf{C} / \mathbf{4} \mathbf{~ h}$ & $\mathbf{1 0 0 0}{ }^{\circ} \mathbf{C} / \mathbf{8 ~ h}$ & $\mathbf{1 0 0 0}^{\circ} \mathbf{C} / \mathbf{1 2} \mathbf{~ h}$ & $\mathbf{1 0 0 0}^{\circ} \mathbf{C} / \mathbf{2 4} \mathbf{~ h}$ \\
\hline $\mathrm{Mn}^{2+}$ & 32.3 & 46.2 & 36.7 & 34.2 \\
$\mathrm{Mn}^{3+}$ & 31.7 & 33.2 & 41.3 & 33.6 \\
$\mathrm{Mn}^{4+}$ & 36.0 & 20.6 & 22.0 & 32.2 \\
$\mathrm{Co}^{2+}$ & 23.6 & 20.9 & 17.7 & 26.3 \\
$\mathrm{Co}^{3+}$ & 76.4 & 79.1 & 82.3 & 73.7 \\
\hline
\end{tabular}

\subsection{Coatings Conductivity}

To evaluate the doping effect, commercial $\mathrm{Mn}_{1.5} \mathrm{Co}_{1.5} \mathrm{O}_{4}$ and $\mathrm{Cu}_{0.3} \mathrm{Mn}_{1.5-\mathrm{x}} \mathrm{Co}_{1.5-\mathrm{y}} \mathrm{O}_{4}$ powder (sintered at $1000{ }^{\circ} \mathrm{C}$ and maintained for $8 \mathrm{~h}, 12 \mathrm{~h}$, and $24 \mathrm{~h}$, respectively) were 
sprayed on $\mathrm{Al}_{2} \mathrm{O}_{3}$ sheets with an atmospheric plasma spray; the parameters are provided in Table 1. During spraying, the spinel powder was injected into the plasma plume, the temperature of which was as high as $15,000{ }^{\circ} \mathrm{C}$, then the injected powder was heated, melted, accelerated, and impacted on the substrate to form coatings. Deoxidization and decomposition of the spinel powder occurred during spraying; therefore, low active phases such as $\mathrm{MnO}_{2}$ and $\mathrm{CoO}$ were generated and left in the coating. As a result of the very short spraying time, only a small part of the powder was decomposed, and most of the powder retained the spinel structure. Before the conductivity measurement, the sample was heated to $800{ }^{\circ} \mathrm{C}$ and maintained for $12 \mathrm{~h}$ to allow the densification of the coating and cure the decomposed phases. As shown in Figure 10, after the heat treatment, significant signals of $\mathrm{MnCo}_{2} \mathrm{O}_{4} / \mathrm{CuMn}_{2} \mathrm{O}_{4}$ were detected, which indicates a transference of low conductive phases to the spinel phase. For this reason, the measured coating conductivity increased with the temperature during preservation with a duration up to $50 \mathrm{~h}$, as shown in Figure 11. The conductivity of the coating prepared with powder sintered for $12 \mathrm{~h}$ was about $51 \mathrm{~S} / \mathrm{cm}$ after $47 \mathrm{~h}$ of preservation. For the coating prepared with powder sintered at $1000{ }^{\circ} \mathrm{C}$ for $8 \mathrm{~h}$ and $24 \mathrm{~h}$, the conductivity was $45 \mathrm{~S} / \mathrm{cm}$ and $49.2 \mathrm{~S} / \mathrm{cm}$, respectively, which are more than double that of the $\mathrm{Mn}_{1.5} \mathrm{Co}_{1.5} \mathrm{O}_{4}$ coating, $23 \mathrm{~S} / \mathrm{cm}$ after $50 \mathrm{~h}$ of preservation. Therefore, by applying $\mathrm{Cu}$ doping, the conductivity of Mn-Co spinel coatings can be significantly improved. Moreover, according to Figures 10 and 11, the coating prepared with powder sintered at $1000^{\circ} \mathrm{C}$ for $8 \mathrm{~h}$ exhibited lower crystallinity and less spinel content, resulting in a coating conductivity lower than that of the $1000{ }^{\circ} \mathrm{C} / 12 \mathrm{~h}$ and $24 \mathrm{~h}$ samples.
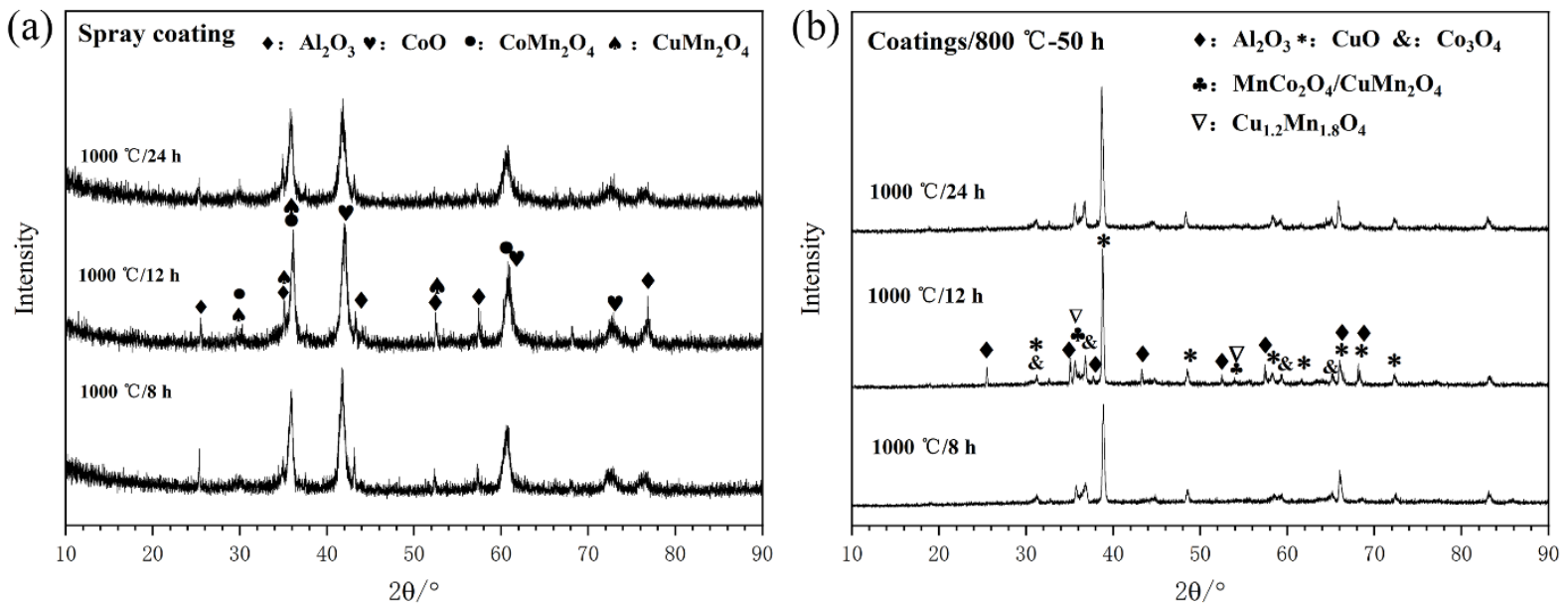

Figure 10. XRD patterns of coatings prepared with sintering powder for different times: (a) spray state; (b) coatings at $800^{\circ} \mathrm{C}$ for $50 \mathrm{~h}$.

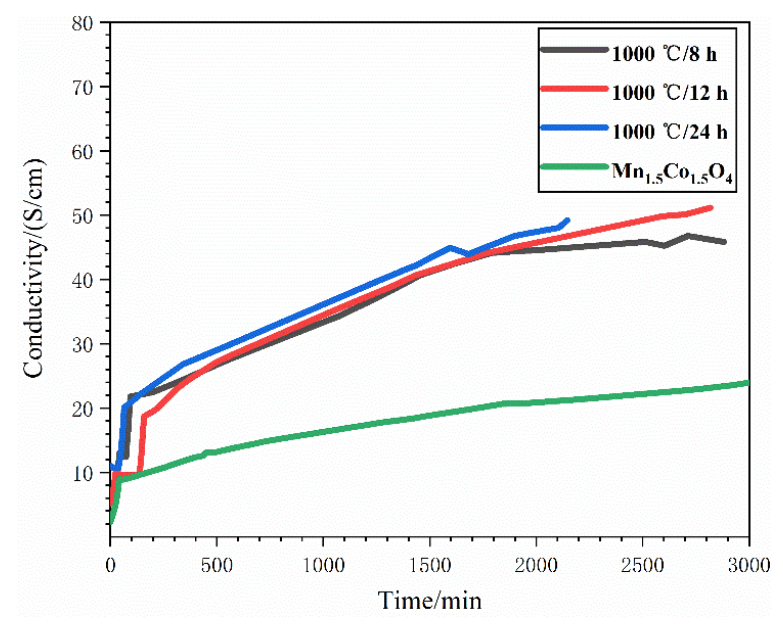

Figure 11. Coatings conductivity prepared from commercial spinel powder and $\mathrm{Cu}_{0.3} \mathrm{Mn}_{1.5-\mathrm{x}} \mathrm{Co}_{1.5-\mathrm{y}} \mathrm{O}_{4}$. 
The sectional morphology and element distribution before and after the conductivity measurement of the best coating $\left(1000{ }^{\circ} \mathrm{C}\right.$ for $\left.12 \mathrm{~h}\right)$ are provided in Figure 12 . After the conductivity measurement, the coating was significantly densified, and no large pores or cracks were visible on the cross-section. The distribution of $\mathrm{Mn}$ and Co exhibited no evident variation, while $\mathrm{Cu}$ was found to be enriched on the coating surface. The enriched $\mathrm{Cu}$ on the surface was then oxidized to $\mathrm{CuO}$ at $800^{\circ} \mathrm{C}$, which limited the conductivity of the coatings. Despite the existence of $\mathrm{CuO}$ on the surface restraining the doping effect, $\mathrm{Cu}$ doping remains a convenient method to significantly promote the conductivity of spinel coatings for SOFC applications.
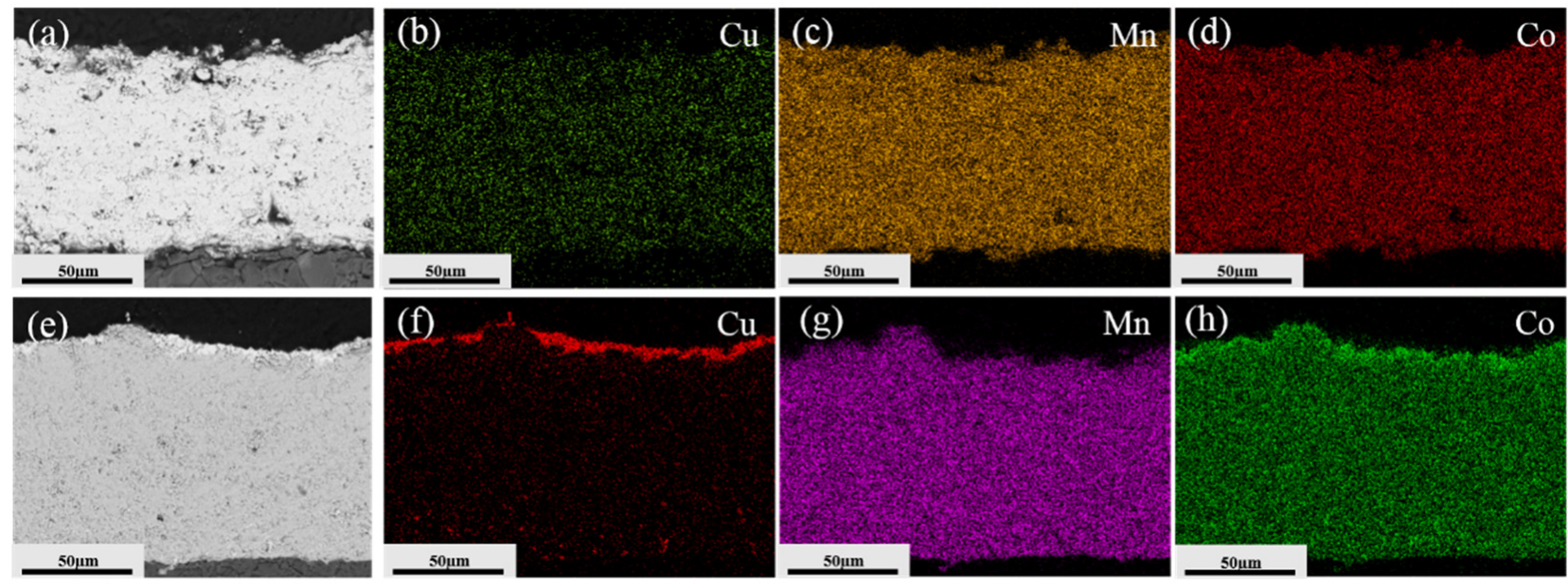

Figure 12. Morphologies and compositions of $\mathrm{Cu}_{0.3} \mathrm{Mn}_{1.5-\mathrm{x}} \mathrm{Co}_{1.5-\mathrm{y}} \mathrm{O}_{4}$ coating: (a-d) before the conductivity measurement; (e-h) after the conductivity measurement.

\section{Conclusions}

The powder $\mathrm{Cu}_{\delta} \mathrm{Mn}_{1.5-\mathrm{x}} \mathrm{Co}_{1.5-\mathrm{y}} \mathrm{O}_{4}(\mathrm{x}+\mathrm{y}=\delta)$ with $\delta=0.3$ showed a better performance than the powder with $\delta=0.1$ or 0.2 . The results of XRD and TG-DSC indicated that increasing the dopant amount resulted in an enhanced doping effect. With $\delta=0.3$, the powder had a better crystallinity and a more conductive spinel phase.

The best doping condition for $\mathrm{Cu}_{0.3} \mathrm{Mn}_{1.5-\mathrm{x}} \mathrm{Co}_{1.5-\mathrm{y}} \mathrm{O}_{4}$ powders was $1000{ }^{\circ} \mathrm{C}$ for $12 \mathrm{~h}$. Under this condition, the crystallization of the spinel phase $\left(\mathrm{MnCo}_{2} \mathrm{O}_{4}\right.$ and $\left.\mathrm{Cu}_{\mathrm{x}} \mathrm{Mn}_{3-\mathrm{x}} \mathrm{O}_{4}\right)$ was the best and the powder was moderately dense. The dopant $\mathrm{Cu}$ was found to be evenly distributed in the powders. The $\mathrm{Cu}_{\mathrm{x}} \mathrm{Mn}_{3-\mathrm{x}} \mathrm{O}_{4}(\mathrm{x}=1,1.2,1.4$ or 1.5) was found to be mainly composed of $\mathrm{CuMn}_{2} \mathrm{O}_{4}$ and was sufficiently stable at elevated temperatures. According to the XPS results, the powder prepared at $1000{ }^{\circ} \mathrm{C}$ for $12 \mathrm{~h}$ consisted of the most $\mathrm{MnCo}_{2} \mathrm{O}_{4}$ and $\mathrm{CuMn} \mathrm{O}_{4}$. When the preservation stage was conducted at $1000{ }^{\circ} \mathrm{C}$ with a duration of less than $12 \mathrm{~h}$ or more than $12 \mathrm{~h}$, less $\mathrm{MnCo}_{2} \mathrm{O}_{4}$ and $\mathrm{Cu}_{\mathrm{x}} \mathrm{Mn}_{3-\mathrm{x}} \mathrm{O}_{4}$ phases were detected.

Coatings were prepared with doped powders using an atmospheric plasma spray. After preservation at $800{ }^{\circ} \mathrm{C}$ for a duration of up to $50 \mathrm{~h}$, the measured conductivity of the prepared coatings reached $45 \mathrm{~S} / \mathrm{cm}, 51 \mathrm{~S} / \mathrm{cm}$, and $49.2 \mathrm{~S} / \mathrm{cm}$, respectively, i.e., two times more than that of the $\mathrm{Mn}_{1.5} \mathrm{Co}_{1.5} \mathrm{O}_{4}$ coating $(23 \mathrm{~S} / \mathrm{cm})$. Although $\mathrm{Cu}$ was enriched on the coating surface after the conductivity measurement, $\mathrm{Cu}$-doping is still an effective method to improve the conductivity of spinel coatings used for interconnect protection in SOFC.

Author Contributions: Formal analysis, Z.J.; investigation, Z.J. and C.S.; methodology, K.W. and T.L.; project administration, M.L.; resources, C.D. (Changguang Deng); supervision, C.D. (Chunming Deng) and Y.D.; writing — original draft, Z.J.; writing—review and editing, T.L. and C.Y. All authors have read and agreed to the published version of the manuscript. 
Funding: This research was funded by the National Key R\&D Program of China grant number 2018YFB1502603, Guangdong Academy of Science grant number 2019GDASYL-0102007, the Foreign Cooperation Platform Project of Guangdong Province grant number 2020A050519001, and Guangzhou Major Projects of Industry-University-Research (IUR) Collaborative Innovation “Surface Treatment and Repair for Key Components of Industrial Gas Turbine (IGT)".

Institutional Review Board Statement: Not applicable.

Informed Consent Statement: Not applicable.

Data Availability Statement: The data presented in this study are available on request from the corresponding author.

Conflicts of Interest: The authors declare no conflict of interest. The founding sponsors had no role in the design of the study; in the collection, analyses, or interpretation of data; in the writing of the manuscript, and in the decision to publish the results.

\section{References}

1. Shong, W.J.; Liu, C.K.; Chen, C.Y.; Peng, C.C.; Tu, H.J.; Fey, G.T.K.; Lee, R.Y.; Kao, H.M. Effects of lanthanum-based perovskite coatings on the formation of oxide scale for ferritic SOFC interconnect. Mater. Chem. Phys. 2011, 127, 45-50. [CrossRef]

2. Stanislowski, M.; Froitzheim, J.; Niewolak, L.; Quadakkers, W.J.; Hilpert, K.; Markus, T.; Singheiser, L. Reduction of chromium vaporization from SOFC interconnectors by highly effective coatings. J. Power Sources 2007, 164, 578-589. [CrossRef]

3. Zou, J.; Song, C.; Wen, K.; Liu, T.; Deng, C.; Liu, M.; Yang, C. The Microstructure and Conductivity Evolution of Plasma-Sprayed $(\mathrm{Mn}, \mathrm{Co})_{3} \mathrm{O}_{4}$ Spinel Coatings during Conductivity Measurements at Elevated Temperature. Coatings 2021, 11, 533. [CrossRef]

4. Grünwald, N.; Sohn, Y.J.; Yin, X.; Menzler, N.H.; Guillon, O.; Vaßen, R. Microstructure and phase evolution of atmospheric plasma sprayed Mn-Co-Fe oxide protection layers for solid oxide fuel cells. J. Eur. Ceram. Soc. 2019, 39, 449-460. [CrossRef]

5. Xin, X.; Zhu, Q.; Liu, Y. Conductive protective coating with heat oxygen-resistance for solid oxide fuel cell (SOFC) alloy interconnect. Surf. Technol. 2019, 48, 22-29. [CrossRef]

6. Jiang, S.P. Development of lanthanum strontium cobalt ferrite perovskite electrodes of solid oxide fuel cells-A review. Int. J. Hydrogen Energy. 2019, 44, 7448-7493. [CrossRef]

7. Tan, K.H.; Rahman, H.A.; Taib, H. Coating layer and influence of transition metal for ferritic stainless steel interconnector solid oxide fuel cell: A review. Int. J. Hydrogen Energy 2019, 44, 30591-30605. [CrossRef]

8. Mah, J.C.W.; Muchtar, A.; Somalu, M.R.; Ghazali, M.J. Metallic interconnects for solid oxide fuel cell: A review on protective coating and deposition techniques. Int. J. Hydrogen Energy 2017, 42, 9219-9229. [CrossRef]

9. Waluyo, N.S.; Park, S.S.; Song, R.H.; Lee, S.-B.; Lim, T.-H.; Hong, J.-E.; Ryu, K.H.; Bin Im, W.; Lee, J.-W. Protective coating based on manganese-copper oxide for solid oxide fuel cell interconnects: Plasma spray coating and performance evaluation. Ceram. Int. 2018, 44, 11576-11581. [CrossRef]

10. Talic, B.; Hendriksen, P.V.; Wiik, K.; Lein, H.L. Thermal expansion and electrical conductivity of $\mathrm{Fe}$ and $\mathrm{Cu}_{\text {doped }} \mathrm{MnCo}_{2} \mathrm{O}_{4}$ spinel. Solid State Ion. 2018, 326, 90-99. [CrossRef]

11. Talic, B.; Hendriksen, P.V.; Wiik, K.; Lein, H.L. Diffusion couple study of the interaction between $\mathrm{Cr}_{2} \mathrm{O}_{3}$ and $\mathrm{MnCo}_{2} \mathrm{O}_{4}$ doped with Fe and Cu. Solid State Ion. 2019, 332, 16-24. [CrossRef]

12. Puranen, J.; Pihlatie, M.; Lagerbom, J.; Bolelli, G.; Laakso, J.; Hyvärinen, L.; Kylmälahti, M.; Himanen, O.; Kiviaho, J.; Lusvarghi, L.; et al. Post-mortem evaluation of oxidized atmospheric plasma sprayed Mn-Co-Fe oxide spinel coatings on SOFC interconnectors. Int. J. Hydrogen Energy 2014, 39, 17284-17294. [CrossRef]

13. Liu, Y.; Fergus, J.W.; Wang, K.; Cruz, C.D. Crystal Structure, Chemical Stabilities and Electrical Conductivity of Fe-Doped Manganese Cobalt Spinel Oxides for SOFC Interconnect Coatings. J. Electrochem. Soc. 2013, 160, F1316-F1321. [CrossRef]

14. Zhu, J.H.; Lewis, M.J.; Du, S.W.; Li, Y. $\mathrm{CeO}_{2}$-doped $(\mathrm{Co}, \mathrm{Mn})_{3} \mathrm{O}_{4}$ coatings for protecting solid oxide fuel cell interconnect alloys. Thin Solid Films 2015, 596, 179-184. [CrossRef]

15. Tseng, H.P.; Yung, T.Y.; Liu, C.K.; Cheng, Y.-N.; Lee, R.-Y. Oxidation characteristics and electrical properties of La- or Ce-doped $\mathrm{MnCo}_{2} \mathrm{O}_{4}$ as protective layer on SUS441 for metallic interconnects in solid oxide fuel cells. Int. J. Hydrogen Energy 2020, 45, 12555-12564. [CrossRef]

16. Gavrilov, N.V.; Ivanov, V.V.; Kamenetskikh, A.S.; Nikonov, A. Investigations of Mn-Co-O and Mn-Co-Y-O coatings deposited by the magnetron sputtering on ferritic stainless steels. Surf. Coat. Technol. 2011, 206, 1252-1258. [CrossRef]

17. Brylewski, T.; Kruk, A.; Bobruk, M.; Adamczyk, A.; Partyka, J.; Rutkowski, P. Structure and electrical properties of Cu-doped Mn-Co-O spinel prepared via soft chemistry and its application in intermediate-temperature solid oxide fuel cell interconnects. J. Power Sources 2016, 333, 145-155. [CrossRef]

18. Xu, Y.; Wen, Z.; Wang, S.; Wen, T. Cu doped Mn-Co spinel protective coating on ferritic stainless steels for SOFC interconnect applications. Solid State Ion. 2011, 192, 561-564. [CrossRef]

19. Sabato, A.G.; Molin, S.; Javed, H.; Zanchi, E.; Boccaccini, A.R.; Smeacetto, F. In-situ Cu-doped MnCo-spinel coatings for solid oxide cell interconnects processed by electrophoretic deposition. Ceram. Int. 2019, 45, 19148-19157. [CrossRef] 
20. Wei, P.; Bieringer, M.; Cranswick, L.M.D.; Petric, A. In situ high-temperature X-ray and neutron diffraction of Cu-Mn oxide phases. J. Mater. Sci. 2010, 45, 1056-1064. [CrossRef]

21. Masi, A.; Bellusci, M.; McPhail, S.J.; Padella, F.; Reale, P.; Hong, J.-E.; Steinberger-Wilckens, R.; Carlini, M. Cu-Mn-Co oxides as protective materials in SOFC technology: The effect of chemical composition on mechanochemical synthesis, sintering behaviour, thermal expansion and electrical conductivity. J. Eur. Ceram. Soc. 2017, 37, 661-669. [CrossRef]

22. Waskowska, A.; Gerward, L.; Olsen, J.S.; Steenstrup, S.; Talik, E. CuMn $\mathrm{O}_{4}$ : Properties and the high-pressure induced Jahn-Teller phase transition. J. Phys. Condens. Matter 2001, 13, 2549-2562. [CrossRef]

23. Hu, Y.Z.; $\mathrm{Su}$, Y.T.; Li, C.X.; Li, C.-J.; Yang, G.-J. Dense $\mathrm{Mn}_{1.5} \mathrm{Co}_{1.5} \mathrm{O}_{4}$ coatings with excellent long-term stability and electrical performance under the SOFC cathode environment. Appl. Surf. Sci. 2020, 499, 143726. [CrossRef]

24. Fan, L.Q.; Huang, J.L.; Wang, Y.L.; Geng, C.-L.; Sun, S.-J.; Huang, Y.-F.; Lin, J.-M.; Wu, J.-H. TiO 2 nanotubes supported ultrafine $\mathrm{MnCo}_{2} \mathrm{O}_{4}$ nanoparticles as a superior-performance anode for lithium-ion capacitors. Int. J. Hydrogen Energy 2021, 46, 35330-35341. [CrossRef]

25. Li, J.; Xiong, S.; Li, X.; Qian, Y. A facile route to synthesize multiporous $\mathrm{MnCo}_{2} \mathrm{O}_{4}$ and $\mathrm{CoMn}_{2} \mathrm{O}_{4}$ spinel quasi-hollow spheres with improved lithium storage properties. Nanoscale 2013, 5, 2045-2054. [CrossRef]

26. Umezawa, Y.; Reilley, C.N. Effect of argon ion bombardment on metal complexes and oxides studied by x-ray photoelectron spectroscopy. Anal. Chem. 1978, 50, 1290-1295. [CrossRef]

27. Vepřek, S.; Cocke, D.L.; Kehl, S.; Oswald, H.R. Mechanism of the deactivation of Hopcalite catalysts studied by XPS, ISS, and other techniques. J. Catal. 1986, 100, 250-263. [CrossRef]

28. Liu, Y.; Song, Z.; Wang, W.; Wang, Z.; Zhang, Y.; Liu, C.; Wang, Y.; Li, A.; Xu, B.; Qi, F. A CuMn ${ }_{2} \mathrm{O}_{4} /$ g-C $_{3} \mathrm{~N}_{4}$ catalytic ozonation membrane reactor used for water purification: Membrane fabrication and performance evaluation. Sep. Purif. Technol. 2021, 265, 118268. [CrossRef]

29. Fang, R.; Liu, F.; Liu, J.; Li, Y. Experimental and theoretical insights into the reaction mechanism of spinel $\mathrm{CuMn}_{2} \mathrm{O}_{4}$ with $\mathrm{CO}$ in chemical-looping combustion. Appl. Surf. Sci. 2021, 561, 150065. [CrossRef]

30. Thaheem, I.; Joh, D.W.; Noh, T.; Lee, K.T. Highly conductive and stable $\mathrm{Mn}_{1.35} \mathrm{Co}_{1.35} \mathrm{Cu}_{0.2} \mathrm{Y}_{0.1} \mathrm{O}_{4}$ spinel protective coating on commercial ferritic stainless steels for intermediate-temperature solid oxide fuel cell interconnect applications. Int. J. Hydrogen Energy 2019, 44, 4293-4303. [CrossRef]

31. Bobruk, M.; Durczak, K.; Dąbek, J.; Dąbek, J.; Brylewski, T. Structure and Electrical Properties of Mn-Cu-O Spinels. J. Mater. Eng. Perform. 2017, 26, 1598-1604. [CrossRef]

32. Joshi, S.; Petric, A. Nickel substituted $\mathrm{CuMn}_{2} \mathrm{O}_{4}$ spinel coatings for solid oxide fuel cell interconnects. Int. J. Hydrogen Energy 2017, 42, 5584-5589. [CrossRef] 